\title{
Monitoring of a Single Point Mutation in the PvCesA3 Allele Conferring Resistance to Carboxylic Acid Amide Fungicides in Plasmopara viticola Populations In Yamanashi Prefecture, Japan
}

\begin{abstract}
Yoshinao Aoki, Yumi Kawagoe, Nozomi Fujimori, Sayumi Tanaka, and Shunji Suzuki, Laboratory of Fruit Genetic Engineering, The Institute of Enology and Viticulture, University of Yamanashi, Kofu, Yamanashi 400-0005, Japan
\end{abstract}

Accepted for publication 14 March 2015. Published 1 May 2015

\section{ABSTRACT}

Aoki, Y., Kawagoe, Y., Fujimori, N., Tanaka, S., and Suzuki, S. 2015. Monitoring of a single point mutation in the PvCesA3 allele conferring resistance to carboxylic acid amide fungicides in Plasmopara viticola populations in Yamanashi prefecture, Japan. Plant Health Progress doi:10.1094/PHP-RS-140041 .

The use of the carboxylic acid amide (CAA) fungicide mandipropamid to manage grapevine downy mildew in vineyards in Japan has been increasing since 2010, because of widespread quinone outside inhibitor fungicide resistance in the Plasmopara viticola population. However, CAA fungicide resistance in $P$. viticola is becoming a serious problem worldwide. In 2013, we monitored for the presence of a single point mutation at codon 1105 of the cellulose synthase gene PvCesA3, which

\section{INTRODUCTION}

Grapevine downy mildew, caused by the oomycete pathogen Plasmopara viticola (Berk. \& MA Curtis) Berl. \& DeToni, is one of the major diseases affecting grapevines. Symptoms include yellow, circular spots with an oily appearance on young leaves (Ash 2000). Then, a white, downy fungal growth appears on the abaxial surface of the leaves. Disease development is favored by temperatures between 13 and $28^{\circ} \mathrm{C}$ and high relative humidity (Ash 2000). Typically, several fungicides are applied to grapevines early in the growing season to control this disease. Mandipropamid, a carboxylic acid amide (CAA) fungicide, was registered as a fungicide against oomycete pathogens in various crops, including grapevine downy mildew, in June 2009 in Japan. The use of Revus (Syngenta Japan, mandipropamid at 0.1-0.25 $\mathrm{kg} / \mathrm{ha}$ ) has been increasing in vineyards in Japan since the 2010 growing season, because quinone outside inhibitor (QoI) fungicide-resistant $P$. viticola isolates are becoming widely distributed throughout Japan (Furuya et al. 2010). Presently, three CAAs, mandipropamid, benthiavalicarb-isopropyl, and dimethomorph, are used for protection against grapevine downy mildew in Japanese vineyards. Mandipropamid-resistant $P$. viticola isolates have already been detected in Europe (Gisi et al. 2007) and the risk of CAA fungicide resistance in $P$. viticola has been raised (FRAC, CAA Working Group Report.

http://www.frac.info/frac/index.html).

A single amino acid substitution at codon 1105 of the cellulose synthase gene $P v C e s A 3$ confers resistance to mandipropamid in $P$. viticola (Blun et al. 2010). On the basis of this finding, we have

Corresponding author: Shunji Suzuki. Email: suzukis@yamanashi.ac.jp confers resistance to mandipropamid in P. viticola samples collected from four vineyards in Yamanashi prefecture in Japan. Five out of 157 samples were found to be heterozygotes, carrying both the mutated and nonmutated $P v \operatorname{Ces} A 3$ alleles. Although CAA fungicide-resistant $P$. viticola isolates have not been reported yet in Japan, the emergence of heterozygous $P$. viticola populations indicates the potential risk of emergence of resistant homozygotes.

developed a PCR restriction fragment length polymorphism (RFLP) assay (Aoki et al. 2011) and an allele-specific primer PCR (ASP-PCR) assay (Aoki et al. 2013a) for the rapid detection of CAA fungicide resistance in P. viticola populations. Using these methods, we reported, for the first time, the emergence of a single point mutation in the $P v C e s A 3$ allele, conferring resistance to mandipropamid, in $P$. viticola populations in Yamanashi prefecture in Japan in 2012 (Aoki et al. 2013b). However, only one isolate had a single point mutation in the PvCesA3 allele heterologously resulting in sensitivity to CAA fungicides. Since CAA fungicide resistance is recessively inherited in the next generation (Gisi et al. 2007), the resistant isolates to CAA fungicides must possess the single point mutation in both alleles (Blum et al. 2010). However, the emergence of sensitive heterozygous $P$. viticola isolates indicates the potential risk of emergence of resistant homozygotes.

The significant isolation among countries in Europe by distance or natural geographical barriers, such as seas and mountains, suggests the stepwise migration of $P$. viticola (Gobbin et al. 2006). Japan is physically isolated from other countries by the sea. Therefore, $P$. viticola populations in Japan are expected to independently evolve under the selection pressure arising from the use of CAA fungicides and to develop CAA fungicide resistance. Monitoring of a single point mutation in the $P v C e s A 3$ allele in $P$. viticola populations in Japan may provide useful information on both the developmental process of CAA fungicide-resistant $P$. viticola and the pest management strategies against future downy mildew infection in Japanese vineyards. Here, we report a survey of a single point mutation in the $P v C e s A 3$ allele of $P$. viticola populations in four vineyards of Yamanashi prefecture in Japan in the 2013 growing season. 


\section{VINEYARD SITE SELECTION AND CHARACTERISTICS}

There are four major grape production regions in Japan (Okayama, Nagano, Yamagata, and Yamanashi prefectures). The total grape yield in each prefecture is over 10,000 tons in an average year. Yamanashi prefecture ranks first in grape production in Japan. During the growing season, the average temperature is $15^{\circ} \mathrm{C}$. The highest seasonal rainfall is generally recorded between June and September with an average annual rainfall of $100 \mathrm{~mm}$. In the present study, we selected four vineyards (vineyard A in Yamanashi city, vineyard B in Kofu city, and vineyards C and D in Koshu city) in Yamanashi prefecture (Fig. 1). The fungicide application programs in the vineyards from 2011 to 2013 growing seasons are summarized in Table 1 . The four vineyards ranged from receiving multiple CAA fungicide applications annually to never receiving any applications; the latter of which served as the negative control.

\section{MONITORING OF A SINGLE POINT MUTATION IN THE PVCESA3 ALLELE AND CAA FUNGICIDE RESISTANCE IN $P$. VITICOLA POPULATIONS IN YAMANASHI PREFECTURE, JAPAN}

Downy mildew-infected leaves and bunches from Vitis vinifera cvs. Cabernet Sauvignon, Chardonnay, and Koshu were collected from the vineyards in Yamanashi prefecture (Fig. 1) in October 2013. One lesion per infected leaf sample (30, 30, 65, and 32 samples from vineyards A, B, C, and D, respectively) was used in this study. An approximately $5 \mathrm{~mm} \times 5 \mathrm{~mm}$ piece was cut from the abaxial surface of the sporulating lesion and transferred into a microtube. DNA was extracted from each sample using a REDExtract-N-Amp plant PCR kit (Sigma, St. Louis, MO) in accordance with the manufacturer's instructions. The CAA fungicide resistance $P v C e s A 3$ allele was detected by ASP-PCR assay (Aoki et al. 2013a). Heterozygotes or homozygotes for the $P v C e s A 3$ allele were detected by PCR-RFLP assay as described previously (Aoki et al. 2011). In addition, an in vivo bioassay for CAA fungicide resistance in $P$. viticola populations was performed using grapevine leaf disks as described previously (Aoki et al. 2011). Briefly, the third to fifth leaves counted from the shoot tip were collected from $V$. vinifera $\mathrm{cv}$. Koshu rooted cuttings. Five leaf disks (10 mm diameter) were placed upside down on $0.5 \%$ water agar in a Petri dish. Mandipropamid (1 $\mathrm{mg} /$ liter, Revus flowable, $23.3 \%$ mandipropamid, Syngenta Japan, Tokyo, Japan), water, or mancozeb (1 mg/liter) was sprayed onto the leaf disks using an atomizer and the leaf disks were dried in a flow cabinet for $24 \mathrm{~h}$. The spores $\left(5.0 \times 10^{4} \mathrm{spores} / \mathrm{ml}\right)$ of $P$. viticola samples that had been maintained on detached leaves were sprayed on the leaf disks. The leaf disks were incubated at $19^{\circ} \mathrm{C}$ in a moist plastic box (approximately $70-90 \%$ relative humidity in the dark). After 7 days, the infection of leaf disks by $P$. viticola was assessed by checking visually for the presence or

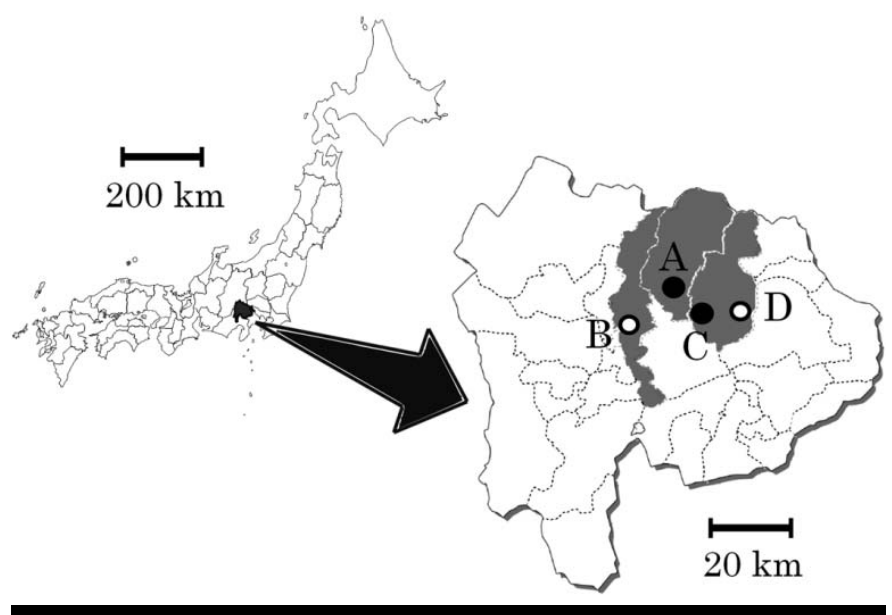

FIGURE 1

Geographical map of Yamanashi prefecture and location of the four vineyards in Yamanashi prefecture. Black circles indicate vineyards $\mathrm{A}$ and $C$ in which carboxylic acid amide fungicide resistance $P v C e s A 3$ alleles in Plasmopara viticola samples were detected. White circles indicate vineyards $B$ and $D$ in which no carboxylic acid amide fungicide resistance $P v C$ CesA3 allele in $P$. viticola samples was detected in this study.

\begin{tabular}{|c|c|c|c|c|c|c|}
\hline \multicolumn{7}{|c|}{$\begin{array}{l}\text { TABLE } 1 \\
\text { Carboxylic acid amide fungicide application in the vineyards sampled in October 2013x }\end{array}$} \\
\hline Year & \multicolumn{2}{|c|}{ Vineyard A } & \multicolumn{2}{|c|}{ Vineyard B } & \multicolumn{2}{|c|}{ Vineyard C } \\
\hline 2011 & $\begin{array}{l}31 \text { May } \\
22 \text { June }\end{array}$ & $\begin{array}{l}\text { Cymoxanil/ } \\
\text { Benthiavalicarb-isopropyl } \\
\text { (0.045 kg a.i. per hectare) } \\
\text { Mandipropamid } \\
\text { (0.136 kg a.i. per hectare) }\end{array}$ & 9 June & $\begin{array}{l}\text { Mandipropamid } \\
(0.217 \text { kg a.i. per hectare })\end{array}$ & $\begin{array}{l}9 \text { May } \\
1 \text { June } \\
24 \text { June }\end{array}$ & $\begin{array}{l}\text { Cymoxanil } \\
\text { /Benthiavalicarb-isopropyl } \\
\text { (0.067 kg a.i. per hectare) } \\
\text { Cymoxanil } \\
\text { /Benthiavalicarb-isopropyl } \\
\text { (0.067 kg a.i. per hectare) } \\
\text { Mandipropamid } \\
\text { (0.155 kg a.i. per hectare) }\end{array}$ \\
\hline 2012 & $\begin{array}{l}21 \text { May } \\
10 \text { June }\end{array}$ & $\begin{array}{l}\text { Cymoxanil } \\
\text { /Benthiavalicarb-isopropyl } \\
\text { (0.045 kg a.i. per hectare) } \\
\text { Mandipropamid } \\
\text { (0.136 kg a.i. per hectare) }\end{array}$ & & & $\begin{array}{l}10 \text { May } \\
12 \text { June }\end{array}$ & $\begin{array}{l}\text { Cymoxanil } \\
\text { /Benthiavalicarb-isopropyl } \\
\text { (0.067 kg a.i. per hectare) } \\
\text { Mandipropamid } \\
\text { (0.155 kg a.i. per hectare) }\end{array}$ \\
\hline
\end{tabular}

${ }^{\mathrm{x}}$ No CAA fungicides were applied to vineyard $\mathrm{D}$. 
absence of symptoms. The in vivo bioassay was performed twice for a total of ten biological replicates per isolate.

Out of the four vineyards assessed, the samples carrying the CAA fungicide resistance $P v C e s A 3$ allele were detected in two vineyards, vineyards A and C (Table 2). ASP-PCR assay detected a single point mutation from GGC to AGC at codon 1105 of $P v C e s A 3$ in two of the 30 single-lesion samples collected from vineyard $A$ and in three of the 65 single-lesion samples collected from vineyard C. In contrast, no resistance allele was detected in any of the 30 and 32 samples collected from vineyards B and D, respectively.

The detection of CAA fungicide resistance $P v C e s A 3$ allele does not necessarily indicate CAA fungicide-resistant $P$. viticola isolates. CAA fungicide resistance is recessively inherited (Gisi et al. 2007). The possession of the single point mutation at codon 1105 of $P v C e s A 3$ in both alleles, a resistant homozygote, is needed for CAA fungicide resistance (Blum et al. 2010). In contrast, a heterozygous $P$. viticola isolate will show the phenotype of sensitivity to CAA fungicides. Therefore, further analysis of $P$. viticola samples is needed to determine whether the samples are resistant homozygotes or sensitive heterozygotes to CAA fungicides. Our PCR-RFLP assay can detect the resistance $P v C e s A 3$ allele in sensitive heterozygotes (Aoki et al. 2011). In this study, PCR-RFLP assay demonstrated that all five samples detected to carry the CAA fungicide resistance allele had the single point mutation at codon 1105 and a nonmutated codon 1105 at the second allele (Fig. 2). This finding suggests two possibilities: (i) if the lesions sampled from the field developed from a single-spore then they are sensitive heterozygotes to CAA fungicides; or (ii) if the lesions developed from multiple spore

\begin{tabular}{|c|c|c|c|c|}
\hline \multicolumn{5}{|c|}{$\begin{array}{l}\text { TABLE } 2 \\
\text { Detection of carboxylic acid amide fungicide resistance } \\
\text { PvCesA3 allele in Plasmopara viticola populations }\end{array}$} \\
\hline \multirow[b]{2}{*}{ Vineyard } & \multicolumn{2}{|c|}{ ASP-PCR ${ }^{X}$} & \multicolumn{2}{|c|}{ PCR-RFLPX } \\
\hline & Tested & Detected & Tested & Digested \\
\hline A & 30 & $2^{y}$ & $2^{y}$ & 2 \\
\hline B & 30 & 0 & 0 & 0 \\
\hline $\mathrm{C}$ & 65 & $3^{z}$ & $3^{z}$ & 3 \\
\hline D & 32 & 0 & 0 & 0 \\
\hline
\end{tabular}

$\mathrm{x}$ This data was confirmed from two replicate experiments.

y Sample nos. A37, A39.

${ }^{\mathrm{z}}$ Sample nos. C105, C107, C289.

\begin{tabular}{|c|c|c|c|c|c|c|}
\hline \multirow{3}{*}{$\begin{array}{l}\text { Sample } \\
\text { nos. }\end{array}$} & \multicolumn{6}{|c|}{$\begin{array}{c}\text { TABLE } 3 \\
\text { In vivo bioassay of carboxylic acid amide fungicide } \\
\text { resistance in Plasmopara viticola samples }\end{array}$} \\
\hline & \multirow{2}{*}{\multicolumn{2}{|c|}{$\frac{\text { Control }^{\mathbf{X}}}{\text { Tested }^{\mathbf{Y}} \text { Infected }}$}} & \multicolumn{2}{|c|}{ Mandipropamidx } & \multicolumn{2}{|c|}{ Mancozeb $^{x}$} \\
\hline & & & Testedy & Infected & Testedy & Infected \\
\hline A37 & 10 & 10 & 10 & 0 & 10 & 0 \\
\hline A39 & 10 & 10 & 10 & 0 & 10 & 0 \\
\hline $\mathrm{C} 105$ & 10 & 10 & 10 & 0 & 10 & 0 \\
\hline $\mathrm{C} 107$ & 10 & 10 & 10 & 0 & 10 & 0 \\
\hline C289 & 10 & 10 & 10 & 0 & 10 & 0 \\
\hline
\end{tabular}

${ }^{\mathrm{x}}$ Control, water treatment; mandipropamid, $1 \mathrm{mg} /$ liter; mancozeb, 1 $\mathrm{mg} /$ liter.

yThis data was pooled across two independent experiments with five replicates per bioassay. sources then there was a heterozygous populations of susceptible and resistant $P$. viticola isolates. However, the in vivo bioassay for CAA fungicide resistance demonstrated that all five samples did not cause any symptoms on the grape leaves treated with $1 \mathrm{mg} /$ liter mandipropamid, which was a lower rate than that commercially applied (Table 3). Taken together with PCR-RFLP assay, we concluded that the five samples were heterozygotes, sensitive to mandipropamid in the present study.

How long would it take for a resistant homozygote to emerge by sexual reproduction in Japan? In this study, three vineyards that applied CAA fungicides and one vineyard that did not apply CAA fungicides in the 2011-2013 growing seasons were investigated. Sensitive heterozygotes were detected in vineyards $\mathrm{A}$ and $\mathrm{C}$, which applied CAA fungicides six and five times in three years, respectively (Table 1). In contrast, the resistant $P v C e s A 3$ allele was not detected in vineyards B (one application in three years) and D (no application). The single point mutation at codon 1105 of $P v C e s A 3$ from one out of 35 single-lesion samples collected from vineyard A in 2012 was detected (Aoki et al. 2013b). A strong pressure arising from future CAA application would increase the frequency of the single point mutation at codon 1105 of $P v C e s A 3$ in $P$. viticola populations. Yamanashi prefecture is located in the main island of Japan (Fig. 1). Because the sea is an effective physical and geographical barrier to gene flow to isolated islands (Rumbou and Gessler 2006), longdistance transmissions of CAA fungicide-resistant $P$. viticola populations to Japan is low to nonexistent. Therefore, the continued monitoring of the CAA fungicide resistance $P v C e s A 3$ allele in $P$. viticola throughout the main island of Japan including Yamanashi prefecture may confirm the hypothesis that CAA

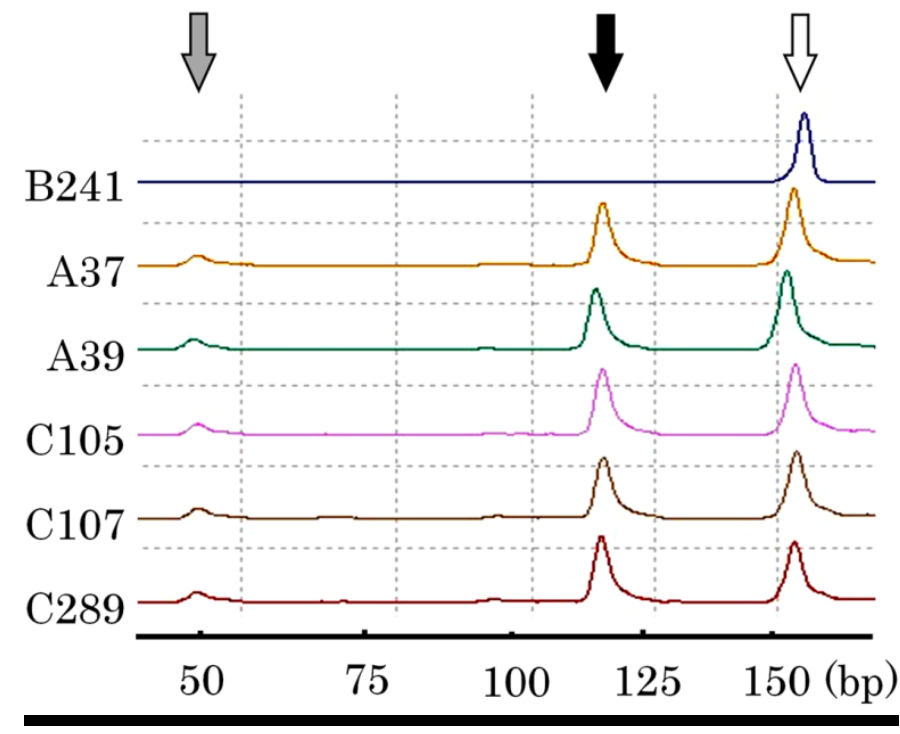

FIGURE 2

PCR-RFLP assay for the carboxylic acid amide fungicide resistance PvCesA3 allele in Plasmopara viticola samples that were identified as carrying the single point mutation at codon 1105 by the PvCesA3 by ASP-PCR assay (Table 2) were digested with Alul. The digested products were applied to the MultiNA-microchip based capillary electrophoresis system. Sample names are indicated on the left. B241, control sample collected from vineyard $\mathrm{B}$, carrying homozygous nonmutated $P v \operatorname{Ces} 3$ alleles; A37 and A39, samples collected from vineyard A. C105, C107, and $C 289$, samples collected from vineyard $C$. The white arrow indicates the nonmutated $P v \operatorname{Ces} A 3$ fragment; the black and gray arrows indicate the digested fragments from the resistance $P v C e s A 3$ fragment carrying the single point mutation from GGC to AGC at codon 1105 . 
fungicide pressure will lead to the emergence and selection of CAA fungicide-resistant $P$. viticola populations and may provide useful information on the developmental process of CAA fungicide-resistant $P$. viticola isolates.

\section{ACKNOWLEDGMENTS}

We are grateful to the four vineyards in Yamanashi prefecture for providing $P$. viticola-infected samples.

\section{LITERATURE CITED}

Ash, G. 2000. Downy mildew of grape. Plant Health Inst. doi:10.1094/PHI-I2000-1112-01.

Aoki, Y., Furuya, S., and Suzuki, S. 2011. Method for rapid detection of $P v C e s A 3$ gene allele conferring resistance to mandipropamid, a carboxylic acid amide fungicide, in Plasmopara viticola populations. Pest Manage. Sci. 67:1557-1561.

Aoki, Y., Hada, Y., and Suzuki, S. 2013a. Development of a multiplex allelespecific primer PCR assay for simultaneous detection of QoI and CAA fungicide resistance alleles in Plasmopara viticola populations. Pest Manage. Sci. 69:268-273.

Aoki, Y., Hashimoto, M., and Suzuki, S. 2013b. Emergence of single point mutation in $P v C e s A 3$, conferring resistance to CAA fungicides, in Plasmopara viticola populations in Japan. Plant Health Progress. doi:10.1094/PHP-2013-0729-01-BR.

Blum, M., Waldner, M., and Gisi, U. 2010. A single point mutation in the novel $P v C e s A 3$ gene confers resistance to the carboxylic acid amide fungicide mandipropamid in Plasmopara viticola. Fung. Gen. Biol. 47:499-510

Furuya, S., Mochizuki, M., Saito, S., Kobayashi, H., Takayanagi, T., and Suzuki, S. 2010. Monitoring of QoI fungicide resistance in Plasmopara viticola populations in Japan. Pest Manage. Sci. 66:1268-1272.

Gisi, U., Waldner, M., Kraus, N., Dubuis, P. H., and Sierotzki, H. 2007. Inheritance of resistance to carboxylic acid amide (CAA) fungicides in Plasmopara viticola. Plant Pathol. 56:199-208.

Gobbin, D., Rumbou, A., Linde, C. C. and Gessler, C. 2006. Population genetic structure of Plasmopara viticola after 125 years of colonization in European vineyards. Mol. Plant Pathol. 7:519-531.

Rumbou, A., and Gessler, C. 2006. Particular structure of Plasmopara viticola populations evolved under Greek island conditions. Phytopathology 96:501-509. 